\title{
Chapter 11 \\ Human and Blended Support to Assist Learning About ICT Integration in (Pre-service) Teacher Design Teams
}

\author{
Ghaida Alayyar and Petra Fisser
}

\section{Introduction}

Jimoyiannis (2010) argued that true learning in the twenty-first century requires students to be able to use ICT, not only for enhancing the memorization of facts, but also for solving problems in real world settings. This means that there is an increased and urgent need to develop teachers who can integrate ICT in their teaching practice. Teacher preparation programs are providing their students (i.e., pre-service teachers) with a variety of ICT tools and opportunities to learn and practice ICTrelated skills; however, many studies have reported that pre-service teachers are unable to use or integrate ICT in their own teaching practices (e.g., Chen, 2008; Fishman \& Davis, 2006; Palak \& Walls, 2009; Tondeur, Roblin, van Braak, Fisser, \& Voogt, 2013; Zhao, Pugh, \& Sheldon, 2002), especially when the ICT courses or training programs focus mainly on the acquisition of basic ICT skills. Several studies have shown that the acquisition of basic ICT skills is not sufficient to develop the ability to teach effectively with ICT (Doering, Veletsianos, Scharber, \& Miller, 2009; Jimoyiannis, 2008; Tondeur et al., 2016; Wetzel, Wilhelm, \& Williams, 2004; Zhao \& Bryant, 2006). For teachers to be able to integrate ICT in their teaching they need an intensive course on the pedagogical use of ICT for a certain subject (Baylor \& Ritchie, 2002; Becker, 2001). Kereluik, Mishra, and Koehler (2010) argued that "teachers need to know how to integrate technologies into their teaching in ways that are flexible, tolerate ambiguity, and connect to deep subject matter learning" (p. 3892). A possible explanation for teachers' lack of ability to use the potential of

\footnotetext{
G. Alayyar $(\square)$

College of Basic Education - The Public Authority for Applied Education and Training, Adailiyah, Kuwait 
ICT to solve pedagogical problems is that teachers experience difficulty in understanding the complex relationships between ICT, pedagogy and content, because these three domains are often taught in isolation in teacher education programs (Koehler, Mishra, Hershey, \& Peruski, 2004; Mishra \& Koehler, 2006; Zhao, 2003).

\section{Background}

\section{ICT Integration in Education}

ICT integration implies that teachers are able to use ICT to introduce, reinforce, extend, enrich, and assess students' mastery of new concepts in a natural, flawless act of selecting the right tool for the learning task (Kelly, 2002). With powerful tools accessible for both teachers and learners, teachers need to realize that their role is changing, and that they can no longer be the source of all information and direct all learning. Teachers must become facilitators of learning who will foster selfmotivated, self-regulated learning in their students.

Churchill (2009) argued that ICT adds a new dimension to teaching effectiveness by enabling teachers to do things that might not be possible within the traditional classroom. Using blogs to publish students' own writing, discuss topics of interest, and engage in peer review and collaboration is an example that provides a new spectrum of teacher-student and student-student interactions beyond the classroom or school environment. Godfrey (as cited in Sang, Valcke, van Braak, \& Tondeur, 2010) summarized the potential of ICT in education as follows: "ICT presents a rich learning environment, allowing the learners to adopt multiple perspectives on complex phenomena, to foster flexible knowledge construction in complex learning domains, and to cater for individual differences (p. 103)". This implies the shift of the teacher role from being a lecturer to being a facilitator, and this also signifies that the learning environment will become more student-centred instead of teachercentred. ICT has fundamentally changed many aspects of educators' lives. Teachers and teacher-educators are no longer focusing on the decision whether to adopt ICT in education or not, but rather on the implementation and integration process (e.g., Angeli \& Valanides, 2009). In order to be successful in this, it is important that teachers have sufficient ICT competencies and are aware of the pedagogical use of ICT in education. Besides ICT competencies, research has found that attitude toward computers and computer self-efficacy are also predictors of ICT use among teachers (Christensen \& Knezek, 1996; Vannatta \& Fordham, 2004).

Harris, Mishra, and Koehler (2009) argued that ICT integration approaches that "did not reflect disciplinary knowledge differences, the corresponding process for developing such knowledge, and the critical role of context ultimately are of limited utility and significance, as they ignore the full complexity of the dynamic realities of teaching effectively with technology (p. 395)". This implies that teachers should also be aware that introducing new ICT tools in teaching not only changes the use of tools in teaching but also what we teach and how we teach, which is an important and often overlooked aspect of many ICT integration interventions. 


\section{Technological Pedagogical Content Knowledge (TPACK)}

Keating and Evans (2001) found that pre-service teachers felt comfortable with ICT in their schoolwork and daily practice, but did not feel confident about using ICT in their future classroom. One possible reason is that the pre-service teachers were lacking "Technological Pedagogical Content Knowledge" (TPACK) (Koehler \& Mishra, 2008; Mishra \& Koehler 2006). TPACK is a framework for understanding and describing the knowledge needed by a teacher for effective ICT integration. The idea of pedagogical content knowledge (PCK) without the explicit technology aspect was first described by Shulman (1987). TPACK builds on this idea through the inclusion of technology. The TPACK framework argues that effective ICT integration for teaching specific content or subject matter requires understanding of the relationships among three components: ICT/Technology (T), Pedagogy (P), and Content $(\mathrm{C})$ in a certain context. TPACK can be defined as anderstanding that emerges from the interaction of Content, Pedagogical, and Technological Knowledge (Koehler \& Mishra, 2008). See Fig. 11.1 for a graphical representation.

Or, as Koehler and Mishra (2008) indicated: "At the heart of good teaching with technology are three core components: content, pedagogy, and technology and the relationship between them" (Koehler \& Mishra, 2008, pp. 11-12). The TPACK

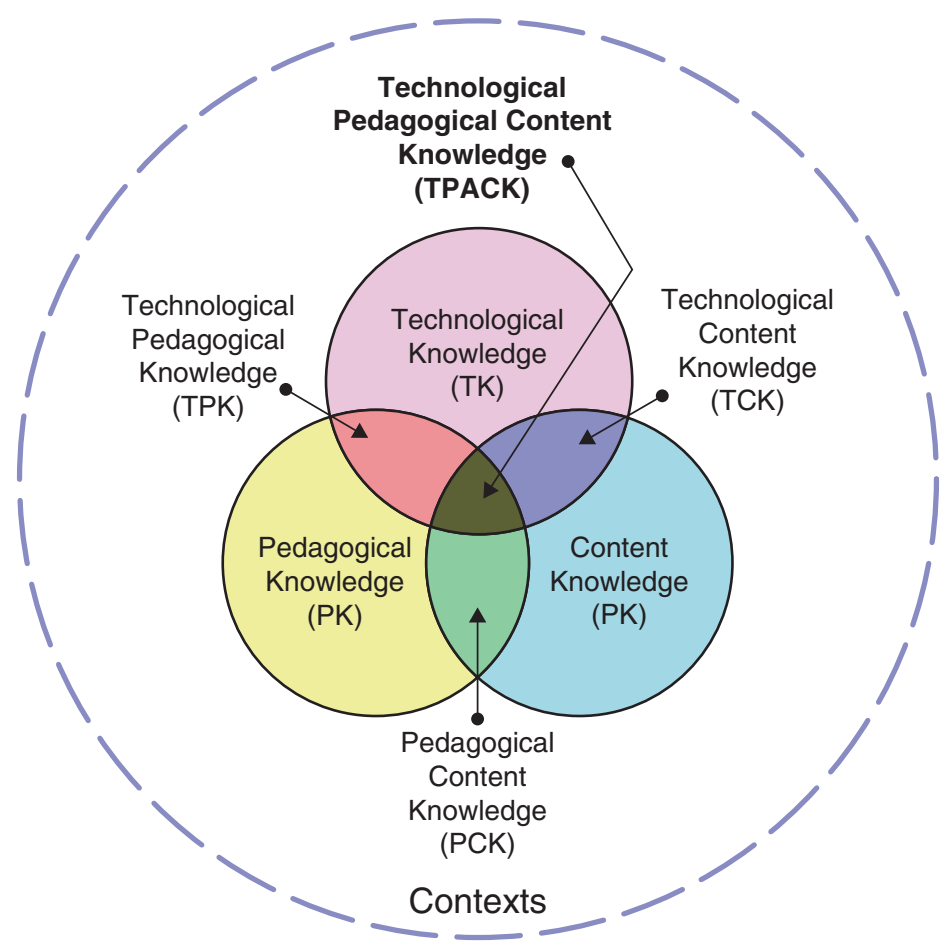

Fig. 11.1 The concept of TPACK. (Adopted from Koehler \& Mishra, 2008) 
framework gives an overview of three primary forms of knowledge a teacher needs to possess or acquire for ICT integration into their teaching: Technological Knowledge (TK), Pedagogical Knowledge (PK) and Content Knowledge (CK), as well as the interplay and intersections between them.

The intersection between the different knowledge domains produces Pedagogical Content Knowledge (PCK) which is the knowledge of teaching specific content, as addressed by Shulman (1987). Technological Pedagogical Knowledge (TPK) is an understanding of how teaching and learning change when a particular ICT application is used. Technological Content Knowledge (TCK) is an understanding of the manner in which ICT and content influence and constrain one another. TPACK is the intersection of all three bodies of knowledge (TK, CK \& PK). Understanding of TPACK is above and beyond understanding of TK, CK, and PK in isolation, in that it emerges from an interaction of content, pedagogy and technology/ICT.

\section{Learning ICT by Design and Design Teams}

The literature has suggested that needs-based, collaborative professional development is effective in developing the competencies teachers need to adequately integrate ICT in their classroom practice (Chandra-Handa, 2001; Figg, 2000; Haughey, 2002; MacDonald, 2008). Kay (2007) conducted a study to compare four strategies used by pre-service teachers to learn about ICT. He found that collaborative strategies for learning were the best predictor of gains in ICT knowledge, and that authentic tasks and collaborative strategies were significant predictors of teacher use of computers in the classroom. Koehler and Mishra (2005) recommended that involving teachers in collaborative authentic problem-solving tasks with ICT is an effective way to learn about ICT, ICT integration processes, and to develop TPACK, a model they called 'learning technology by design' (Koehler \& Mishra, 2005).

The learning technology by design approach seeks to put teachers in the role of designers of ICT-enhanced environments as they work collaboratively in small groups to develop ICT solutions to authentic pedagogical problems. By participating in the design process, teachers build competencies that are sensitive to the subject matter (instead of learning the technology in general) and to specific instructional goals (instead of general ones) relevant for addressing the subject matter. In the view of Mishra and Koehler (2003), every act of design is always a process of weaving together components of ICT, content, and pedagogy.

Traditional approaches to learning to use ICT in education make teachers consumers of knowledge about ICT tools, with the hope that they will be able to apply this general knowledge to solving problems in their specific classrooms (Koehler \& Mishra, 2005). The learning technology by design approach is based upon different educational strategies that address the potential of design-based activities for learning, such as constructivism or constructionism (Cole, 1997; Harel, 1991; Harel \& Papert, 1991; Vygotsky, 1978) and the theory of problem-based learning (Blumenfeld, Marx, Soloway, \& Krajcik, 1996; Krajcik et al., 1998). Problem-based 
learning and learning technology by design often occur over an extended period of time; they are learner-centred, interdisciplinary, ill-structured, and related to the real world by engaging students in authentic activities.

\section{Research Context}

The context of this study was the teacher preparation program at the Public Authority of Applied Education \& Training (PAAET) in Kuwait, in particular, the science teacher preparation program at PAAET. The teacher preparation program includes some courses on ICT skills, but only as stand-alone ICT skills courses, on the assumption that acquiring ICT skills will lead automatically to effective integration of ICT by pre-service teachers in their future classroom practice.

A feasibility study (Alayyar, 2011) showed that pre-service science teachers at PAAET had a positive attitude toward ICT, that they had basic ICT skills and that they were aware of ICT and its potential role in education. But they were not sure about their ability to integrate ICT into their teaching. They did not consider themselves to be ICT-integrating teachers, which was attributed to the following reasons: (1) the ICT focused courses do not provide students with the ability to integrate ICT in practice; (2) there is limited ICT integration throughout the program, so the preservice teachers do not experience authentic use of ICT in teaching and learning; and (3) traditional teaching methods are used throughout their preparation program at PAAET.

Based on the previously mentioned results and on a review of the literature, suggestions to support pre-service teachers to better understand and experience the role of ICT in education were proposed: (1) to help pre-service teachers understand how student-centred practices, supported by ICT, impact student learning; (2) to provide pre-service teachers with concrete examples of what teaching with ICT looks like in practice, and to facilitate change in teachers' knowledge and attitudes towards ICT; (3) to provide pre-service teachers with opportunities to explore and experiment with the pedagogical uses of ICT tools to help pre-service teachers to become more confident about integration; and 4) to work in an authentic, collaborative learning environment as a suitable strategy to prepare pre-service teachers to integrate ICT in their future practice.

\section{Research Approach}

\section{Design-Based Research}

The research approach adopted in our study is design-based research, which is a systematic method characterized by observing and addressing complex problems in their natural setting with the aim to improve educational practice through iterative 
cycles of analysis, design, development, and implementation. Reeves (2006) indicated that design-based research has two objectives: to develop creative approaches for solving performance or teaching/learning problems, and at the same time to construct a body of design principles that informs theory and could be used to guide efforts in future development. Design-based research is challenging because the researcher not only needs to understand what is happening in a particular context, the researcher should also be able to show the relevance of the findings from the context of the intervention to other contexts.

\section{Research Questions}

Two questions guided the research in this study:

1. What changes can be observed in the TPACK, ICT skills, and attitudes toward ICT of pre-service science teachers who participated in DTs?

2. Do Blended Support and Human Support differ in their contribution to these effects?

\section{Intervention}

Two iterations of the intervention were studied. For the first iteration, pre-service teachers $(n=61$, all female) in the final year of their science education program worked in Design Teams (DTs; three to four pre-service students) and were coached by ICT, pedagogy, and content experts, to find an ICT-related solution for an authentic educational problem that they could encounter in their teaching practice. The DTs had to select science content and a suitable ICT tool for teaching this content, taking into account the affordances and constraints of the tool, and to determine teaching strategies for using ICT with a learner-centred focus. At the end of the course, the DTs had to present their solution in class, together with a lesson plan, and an ICT integration plan. The intervention lasted 12 weeks, 2 hours per week.

In the second iteration, the pre-service teachers ( $n=78$, all female) were separated into two groups; the first group was offered human support (HS; $n=22$, all female) from an ICT, pedagogy and content expert (similar to the previous study) and the second group was offered blended support (BS; $n=56$, all female), In the BS-condition, the experts did not attend the class unless the DTs needed them. The BS was an online support portal in Moodle, which contained tutorials on how to use different kinds of software, examples of lesson plans that integrate ICT, a matrix of different ICT applications with suitable teaching methods, and examples or URL 
links on using ICT in science education. The portal also provide online expert support through a chat tool and offered a workplace for DTs to share documents, and a discussion forum to reflect on what was going on in class, and to answer weekly questions. Besides using the portal, the pre-service teachers in the BS condition had the opportunity to consult the experts face to face. The assignment for the preservice teachers was similar to the first iteration. This intervention also lasted 12 weeks, 2 hours per week.

\section{Data Collection and Analysis}

Several instruments were used to answer the research questions. Data were collected at the start and end of the intervention to determine pre-service teachers' development of TPACK, their ICT skills and their attitudes towards ICT. The following instruments were administered: the TPACK survey (Schmidt et al., 2009), the ICT skills test and the ICT skills questionnaire [based on Milken Exchange on Educational Technology (1999) and the Technology Proficiency Self-Assessment (TPSA; Ropp, 1999)] and the Teachers' Attitude toward Computers questionnaire (TAC; Christensen \& Knezek, 1996).

At the end of the intervention, the DTs were asked to submit a logbook in which they described the problems they faced during the design process, how they solved these problems, from whom they got support and assistance, and the different activities that occurred within the DT during the design process.

In the first iteration, the pre-service teachers completed an attitude toward teamwork questionnaire to understand their attitude towards working in teams; they also participated in a semi-structured interview to assess individual student opinions about their TPACK understanding and experience, and the support and help a DT needs during the design process. In the second iteration, the teams participating in the BS condition were interviewed to gather their opinion about the BS. To assess preservice students' understanding of TPACK and whether they could relate TPACK to their practice or experience during their in-school training or within their preparation program, all students were asked to provide a written reflection on those topics.

To analyse the quantitative data, means and standard deviations were calculated. Inferential statistics were used to determine differences between pre-post measures and/or different conditions (second iteration). To analyse student understanding of TPACK (first iteration: semi-structured interviews; second iteration: TPACK reflection questionnaire), an assessment rubric (Alayyar, Fisser, \& Voogt, 2011) was used. The logbooks were analysed by grouping the ICT needs or problems into different groups in relation to TPACK; then items related to TK were sub-grouped according to their functions, such as photo editing, video editing, presentation, sound editing, animation, tables, and database. Students' opinions about BS (second iteration) were summarized. 


\section{Main Findings}

\section{First Iteration: TPACK and Teacher Design Teams}

It was expected that by working in DTs, the pre-service science teachers would experience student-centred practices through an authentic, active and collaborative learning environment. Designing an ICT-enhanced lesson would give the preservice science teachers opportunities to explore and experiment with the ICT tools and to experience the pedagogical uses of ICT tools in order to understand what teaching with ICT will look like in practice and how integration of ICT in science curriculum will impact student learning, and would provide the pre-service science teachers with concrete examples of effective ICT integration in science education. The whole experience would support the development of competencies needed by pre-service science teachers for ICT integration.

The findings of this study showed that during the design process, the pre-service science teachers developed their ICT skills and started thinking about ICT as a tool for achieving instructional objectives, rather than considering ICT as an end in itself. The pre-service teachers became active learners, collaborated with different team members, learned by doing and experimented with different kinds of ICT tools to solve the pedagogical problems they encountered. This study provided preservice science teachers at PAAET with the competencies required for an ICTintegrating teacher. The results of the study showed that the ICT skills of the pre-service teachers increased significantly after they worked in DTs to develop or design a solution for a problem related to the specific science content by using a suitable pedagogy and appropriate ICT tools. The pre-service teachers developed a positive attitude toward both ICT and teamwork, and their TPACK had increased after working in DTs. This meant that the pre-service teachers had positive experiences with using ICT and gained ICT-related skills. Additionally, the pre-service teachers reported an increase in the usefulness and ease of ICT use at the end of the intervention, which indicated that the pre-service teachers supposedly increased their confidence and competence in using ICT. The findings provided evidence that having the pre-service science teachers at PAAET work in a DT fostered their development of TPACK.

\section{Second Iteration: Blended Support for Learning}

From the first iteration, the experts who coached the pre-service science teachers indicated that the face-to-face support they provided to the DTs during the course was essential in guiding students' thinking toward TPACK. However, both the experts and the pre-service science teachers acknowledged that supporting the DTs face-to-face was time consuming and asserted that more flexibility related to time and delivery would be an important feature of an environment supporting the 
development of TPACK in DTs. Beside the flexibility, the pre-service teachers stressed the need for a support system or environment in the Arabic language. Since students at the teacher preparation program at PAAET are used to a teacher-centred approach, an online environment that completely replaced the support of the expert instructors therefore might not be an effective strategy. For this reason, a blended approach to supporting the DTs was explored in this study. The second iteration intended to explore whether providing BS (on-line support along with face-to-face support by expert instructors) for learning could be an effective and efficient alternative to support the development of TPACK in the pre-service science teachers while working in DTs.

The results from this iteration indicated that both the HS and BS conditions showed significant positive effects on the pre-service teachers' attitude, knowledge, and skills needed for ICT integration. This leads to the conclusion that human support and blended support conditions are successful alternatives for supporting the pre-service teachers. However, pre-service teachers in the BS condition showed higher gains in positive attitudes toward ICT, Technological Pedagogical Knowledge (TPK), and Technological Knowledge (TK). No differences between the two conditions were found in the anxiety and frustration constructs toward computers, ICT skills (test and survey) and - except for TK and TPK - the other aspects of TPACK. Based on the findings of this study it was concluded that applying the DTs approach combined with BS is beneficial for the pre-service teachers and the instructors who guide them. The pre-service teachers showed higher gains in positive attitudes toward ICT, TPK TK, they became more experienced with ICT use, and they experienced a student-centred approach. For the instructors, the BS for learning meant an effective and, above all, a more efficient way of supporting the pre-service teachers.

\section{Conclusion}

This study used DTs as a pedagogical approach to prepare pre-service science teachers for ICT integration in their practice. The findings of this study showed that ICT integration through working in DTs proved to be a promising strategy in preservice teacher education programs, for several reasons. First, it helped to develop the competencies of pre-service teachers at PAAET for ICT integration. By using DTs, the pre-service science teachers learned about ICT tool affordances and constraints for solving teaching and learning problems, ICT-related skills, and design processes. This approach to ICT integration moved pre-service teachers from being passive learners and consumers of ICT to being more active learners and producers/ designers of ICT by learning how to use existing hardware and software in creative and situation-specific ways to accomplish their teaching goals. Subsequently, they were able to integrate the available ICT in their daily lesson plans and classroom practice. This not only led to more and effective integration of ICT in teaching and learning, but pre-service teachers also experienced a student-centred approach, 
which they can apply in their future teaching activities. Second, working in DTs and engaging in the design process for educational reform have been shown to generate greater ownership and commitment toward the education reform (Cviko, McKenney, \& Voogt, 2015; Nieveen, Handelzalts, \& Van den Akker, 2005) This means that working in DTs on ICT integration during their pre-service teacher education program at PAAET may strengthen the ownership of the pre-service teachers toward the ICT integration process. Kereluik et al. (2010) indicated that it is important to realize that ICT-based interventions will not reach fruition unless the teachers take ownership. It is therefore recommended that the teacher preparation program at PAAET adopt the DT approach in its curriculum in order to realize ICT integration not only in the future practice of the pre-service teachers, but also in the teacher preparation program itself.

The results of this study showed that both HS and BS are effective in developing the competencies and attitudes pre-service teachers need to integrate ICT in their teaching. The BS environment also included the possibility of communication among team members, between different teams, and with the course instructor. The pre-service teachers and the expert instructors appreciated the BS with the combination of support and guidance provided by the instructors and the flexibility of an online environment. An advantage of BS over HS was that the pre-service teachers experienced the use of ICT tools in an ICT environment for their own learning. In addition, the BS mode is more than the HS mode in providing the pre-service teachers with experiences in learning through a student-centred approach. These experiences suggest that at PAAET, DTs in a BS mode could be a useful format for supporting pre-service teachers in developing their abilities for the integration of ICT.

Extra time is needed to get used to, and to practice ICT competencies in real classroom settings (Tondeur, Pareja Roblin, van Braak, Voogt, \& Prestridge, 2017). Sustaining the development of TPACK needs to be fostered through real teaching experiences because building a strong TPACK knowledge base is a long-term trajectory that goes beyond pre-service teacher education in formal settings (Fishman \& Davis, 2006; Voogt, Fisser, Tondeur, \& van Braak, 2016). Therefore, it is recommended that graduates of the teacher preparation program should have the opportunity to engage in lifelong learning opportunities through an additional (in-service) program. This could be done by providing an online learning support system that could help pre-/in-service teachers in the development of ICT integration in education. This environment can act as a learning support, and also as a communication tool to exchange ideas among peers and experts. At the same time, the teachers will learn about ICT integration by doing (Tran, Berg, Ellermeijer, \& Beishuizen, 2015).

This study focused on the development of the attitudes, knowledge and skills needed by pre-service teachers to be able to integrate ICT in their future teaching practice. The development of competencies needed to integrate ICT in teaching and learning practices is a long-term trajectory. To better understand and support the professional learning of practicing teachers regarding the use of ICT for teaching and learning in DTs, further research is needed to guide the organization, composition 
and activities of DTs for fostering the development of TPACK in practicing teachers.

\section{References}

Alayyar, G. (2011). Developing pre-service teacher competencies for ICT integration through design teams (Doctoral dissertation). Enschede, the Netherlands: University of Twente.

Alayyar, G., Fisser, P., \& Voogt, J. (2011). ICT integration through design teams in science teacher preparation. International Journal of Learning Technology, 6(2), 125-145.

Angeli, C., \& Valanides, N. (2009). Epistemological and methodological issues for the conceptualization, development, and assessment of ICT-TPCK: Advances in Technological Pedagogical Content Knowledge (TPCK). Computers \& Education, 52(1), 154-168. https:// doi.org/10.1016/j.compedu.2008.07.006

Baylor, A. L., \& Ritchie, D. (2002). What factors facilitate teacher skill, teacher morale, and perceived student learning in technology-using classrooms? Computers \& Education, 39(4), 395-414. https://doi.org/10.1016/s0360-1315(02)00075-1

Becker, H. J. (2001). How are teachers using computers in instruction? Paper presented at the Annual Meeting of the American Educational Research Association, Seattle, WA.

Blumenfeld, P. C., Marx, R. W., Soloway, E., \& Krajcik, J. (1996). Learning with peers: From small group cooperation to collaborative communities. Educational Researcher, 25(8), 37-40.

Chandra-Handa, M. (2001). Leading academic change - Through connective leadership and learning. In J. Price et al. (Eds.), Proceedings of Society for Information Technology \& teacher education international conference 2001 (pp. 488-493). Chesapeake, VA: AACE.

Chen, C. H. (2008). Why do teachers not practice what they believe regarding technology integration? The Journal of Educational Research, 102(1), 65-75.

Christensen, R., \& Knezek, G. (1996). Constructing the Teachers' Attitudes toward Computers (TAC) questionnaire. Paper presented at the Southwest Educational Research Association Annual Conference, New Orleans, LA.

Churchill, D. (2009). Educational applications of web 2.0: Using blogs to support teaching and learning. British Journal of Educational Technology, 40(1), 179-183. https://doi. org/10.1111/j.1467-8535.2008.00865.x

Cole, M. (1997). Cultural psychology: A once and future discipline. Cambridge, MA: The Belknap Press of Harvard University Press.

Cviko, A., McKenney, S., \& Voogt, J. (2015). Teachers as co-designers of technology-rich learning activities for emergent literacy. Technology, Pedagogy and Education, 24(4), 443-459. https:// doi.org/10.1080/1475939X.2014.953197

Doering, A., Veletsianos, G., Scharber, C., \& Miller, C. (2009). Using the technological pedagogical, and content knowledge framework to design online learning environments and professional development. Journal of Educational Computing Research, 41(3), 319-346.

Figg, C. B. (2000). Relationships between selected elementary teachers' beliefs and educational technology use (Unpublished dissertation). Austin, TX: University of Texas.

Fishman, B., \& Davis, E. (2006). Teacher learning research and the learning science. In R. K. Sawyer (Ed.), Cambridge handbook of the learning sciences (pp. 535-550). New York: Cambridge University Press.

Harel, I. (1991). Children designers: Interdisciplinary constructions for learning and knowing mathematics in a computer-rich school. Norwood, NJ: Ablex Publishing Corporation.

Harel, I., \& Papert, S. (1991). Constructionism. Norwood, NJ: Ablex Publishing Corporation. 
Harris, J., Mishra, P., \& Koehler, M. (2009). Teachers' technological pedagogical content knowledge and learning activity types: Curriculum-based technology integration reframed. Journal of Research on Technology in Education, 41(4), 393-416.

Haughey, M. (2002). Canadian research on information and communications technologies: A state of the field. Retrieved May 15, 2011 from http://citeseerx.ist.psu.edu/viewdoc/download?doi=1 0.1.1.84.998\&rep=rep1\&type $=$ pdf

Jimoyiannis, A. (2008). Factors determining teachers' beliefs and perceptions of ICT in education. In A. Cartelli \& M. Palma (Eds.), Encyclopaedia of information communication technology (pp. 321-334). Hershey, PA: IGI Global.

Jimoyiannis, A. (2010). Designing and implementing an integrated technological pedagogical science knowledge framework for science teachers professional development. Computers \& Education, 55(3), 1259-1269. https://doi.org/10.1016/j.compedu.2010.05.022

Kay, R. (2007). A formative analysis of how pre-service teachers learn to use technology. Journal of Computer Assisted Learning, 23(5), 366-383.

Keating, T., \& Evans, E. (2001). Three computers in the back of the classroom: Pre-service teachers' conceptions of technology integration. Paper presented at the Annual meeting of the American Educational Research Association, Seattle, WA.

Kelly, M. G. (Ed.). (2002). National educational technology standards for teachers: Preparing teachers to use technology (1st ed.). Eugene, OR: International Society for Technology in Education.

Kereluik, K., Mishra, P., \& Koehler, M. (2010). Reconsidering the T and C in TPACK: Repurposing technologies for interdisciplinary knowledge. In D. Gibson \& B. Dodge (Eds.), Proceedings of SITE 2010 - Society for Information Technology \& teacher education international conference (pp. 3892-3899). San Diego, CA: Association for the Advancement of Computing in Education (AACE). http://www.editlib.org/p/33987

Koehler, M. J., \& Mishra, P. (2005). What happens when teachers design educational technology? The development of technological pedagogical content knowledge. Journal of Educational Computing Research, 32(2), 131-152.

Koehler, M. J., \& Mishra, P. (2008). Introducing TPCK. In The AACTE Committee on Innovation and Technology (Ed.), Handbook of technological pedagogical content knowledge (TPCK) for educators (pp. 3-29). New York: Routledge.

Koehler, M. J., Mishra, P., Hershey, K., \& Peruski, L. (2004). With a little help from your students: A new model for faculty development and online course design. Journal of Technology and Teacher Education, 12(1), 25-55.

Krajcik, J. S., Blumenfeld, P., Marx, R. W., Bass, K. M., Fredricks, J., \& Soloway, E. (1998). Middle school students' initial attempts at inquiry in project-based science classrooms. The Journal of the Learning Sciences, 7, 313-350.

MacDonald, R. J. (2008). Professional development for information communication technology integration: Identifying and supporting a community of practice through design-based research. Journal of Research on Technology in Education, 40(4), 429-445.

Milken Exchange on Educational Technology Report. (1999). Will new teachers be prepared to teach in a digital age? A national survey on information technology in teacher education. Retrieved on 22 June 2009. Available at http://www.milkenexchange.org/research/iste_results. html

Mishra, P., \& Koehler, M. J. (2003). Not "what" but "how": Becoming design-wise about educational technology. In Y. Zhao (Ed.), What teachers should know about technology: Perspectives and practices (pp. 99-122). Greenwich, CT: Information Age Publishing.

Mishra, P., \& Koehler, M. (2006). Technological pedagogical content knowledge: A new framework for teacher knowledge. Teachers College Record, 108(6), 1017-1054.

Nieveen, N., Handelzalts, A., \& Van den Akker, J. (2005). Teacher design teams in view of school-based curriculum development. Paper presented at the American Educational Research Association Annual Meeting, Montreal, Canada. 
Palak, D., \& Walls, R. T. (2009). Teachers' beliefs and technology practices: A mixed methods approach. Journal of Research on Technology in Education, 41(4), 417-441.

Reeves, T. C. (2006). Design research from a technology perspective. Educational Design Research, 1(3), 52-66.

Ropp, M. M. (1999). Exploring individual characteristics associated with learning to use computers in pre-service teacher preparation. Journal of Research on Computing in Education, 31(4), 402-424.

Sang, G., Valcke, M., van Braak, J., \& Tondeur, J. (2010). Student teachers' thinking processes and ICT integration: Predictors of prospective teaching behaviours with educational technology. Computers \& Education, 54, 103-112.

Schmidt, D. A., Baran, E., Thompson, A. D., Punya, M., Koehler, M. J., \& Shin, T. S. (2009). Technological pedagogical content knowledge (TPACK): The development and validation of an assessment instrument for pre-service teachers. Journal of Research on Technology in Education, 42, 123-149.

Shulman, L. (1987). Knowledge and teaching: Foundations of the new reform. Harvard Educational Review, 57(1), 1-22.

Tondeur, J., Roblin, N. P., van Braak, J., Fisser, P., \& Voogt, J. (2013). Technological pedagogical content knowledge in teacher education: In search of a new curriculum. Educational Studies, 39(2), 239-243. https://doi.org/10.1080/03055698.2012.713548

Tondeur, J., Aesaert, K., Pynoo, B., van Braak, J., Fraeyman, N., \& Erstad, O. (2016). Developing a validated instrument to measure preservice teachers' ICT competencies: Meeting the demands of the 21st century. British Journal of Educational Technology, 48, 462-472.

Tondeur, J., Pareja Roblin, N., van Braak, J., Voogt, J., \& Prestridge, S. (2017). Preparing beginning teachers for technology integration in education: Ready for take-off? Technology, Pedagogy and Education, 26(2), 157-177.

Tran, B., Berg, E., Ellermeijer, T., \& Beishuizen, J. (2015). Development of a course on integrating ICT into inquiry-based science education. Three case studies in The Netherlands. Nuovo Cimento C, 38(3), 1-18.

Vannatta, R. A., \& Fordham, N. (2004). Teacher dispositions as predictors of classroom technology use. Journal of Research on Technology in Education, 36(3), 253-271.

Voogt, J., Fisser, P., Tondeur, J., \& van Braak, J. (2016). Using theoretical perspectives in developing an understanding of TPACK. In M. Herring, M. J. Koehler, \& P. Mishra (Eds.), Handbook of technological pedagogical content knowledge (TPACK) for educators (2nd ed., pp. 33-51). New York: Routledge.

Vygotsky, L. S. (1978). Mind in society: The development of higher psychological processes. Cambridge, MA: Harvard University Press. 
Wetzel, K., Wilhelm, L., \& Williams, M.K. (2004). The introductory technology course: A tool for technology integration. Contemporary Issues in Technology and Teacher Education [Online serial], 3(4). Retrieved from http://www.citejournal.org/vol3/iss4/general/article4.cfm

Zhao, Y. (Ed.). (2003). What should teachers know about technology? Perspectives and practices. Greenwich, CT: Information Age Publishing.

Zhao, Y., \& Bryant, F. L. (2006). Can teacher technology integration training alone lead to high levels of technology integration? A qualitative look at teachers' technology integration after state mandated technology training. Electronic Journal for the Integration of Technology in Education, 5, 53-62.

Zhao, Y., Pugh, K., \& Sheldon, S. (2002). Conditions for classroom technology innovations. Teachers College Record, 104(3), 482-515.

Open Access This chapter is licensed under the terms of the Creative Commons Attribution 4.0 International License (http://creativecommons.org/licenses/by/4.0/), which permits use, sharing, adaptation, distribution and reproduction in any medium or format, as long as you give appropriate credit to the original author(s) and the source, provide a link to the Creative Commons licence and indicate if changes were made.

The images or other third party material in this chapter are included in the chapter's Creative Commons licence, unless indicated otherwise in a credit line to the material. If material is not included in the chapter's Creative Commons licence and your intended use is not permitted by statutory regulation or exceeds the permitted use, you will need to obtain permission directly from the copyright holder.

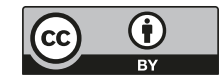

